\title{
Sustainability After Project Completion: Evidence from the GEF
}

\author{
Neeraj Kumar Negi and Molly Watts Sohn
}

\section{Abstract}

This chapter examines the extent to which completed GEF projects are sustainable and the factors affecting sustainability. We considered only those projects that were covered through postcompletion evaluation at least 2 years after implementation completion, and where the evaluation reports provided adequate information related to observed sustainability during the postcompletion period. We assessed 62 projects to meet the selection criteria, then completed a desk review of the postcompletion evaluation reports and other relevant documents for these projects to assess the extent to which the project outcome was sustainable.

We found that the projects covered through postcompletion evaluations were generally sustainable, with the sustainability outlook deteriorating for some projects while improving for others. The incidence of the catalytic processes that enhance sustainability-sus-

Nina Hamilton, Ritu Kanotra, Selin Erdogan, and Spandana Battula provided research assistance support for this chapter.

N. K. Negi $(\bowtie) \cdot$ M. W. Sohn

Global Environment Facility Independent Evaluation Office, Washington, DC, USA

e-mail: nnegi1@thegef.org taining, mainstreaming, replication, scalingup, and market change-was higher at postcompletion evaluation, as the passage of time allows long-term project outcomes to manifest. At the project level, we observed these catalytic processes in a wider set of activities at postcompletion evaluation than at implementation completion. Factors such as financial support for follow-up, political support, follow-up by and capacities of the executing agency, stakeholder buy-in, and project design seem to play a crucial role in determining project sustainability.

\section{Introduction}

International development cooperation is aimed at helping the recipient countries address their development challenges. A significant share of this aid is provided to the recipients through a project-based modality. For projects to achieve their long-term objectives, it is important that the infrastructure created and approaches promoted by these projects are sustained. However, the extent to which this takes place typically is not ascertained because reporting on project performance usually culminates at the completion of an implementation. This chapter aims to address this gap by bringing forth evidence on postcompletion performance of GEF-supported projects. 
International development agencies generally assess sustainability of their projects at completion of implementation. However, at that point, most of the project benefits are yet to accrue, so assessments of project sustainability generally estimate likelihood of future net benefit flows. Assessment of actual sustainability after implementation completion-say, 2 years or more after completion-is relatively rare. This is primarily because taking stock of the actual accrual of benefits during the postcompletion period is costly, relevant information may be difficult to access, and responsibility for conducting these evaluations may not be clear. As a result, little is known in terms of observed sustainability of development projects.

The evidence presented in this chapter is based on the post completion performance of projects supported by the Global Environment Facility (GEF). As of January 2021, the GEF has provided more than $\$ 21$ billion through 5000 projects in 170 countries. These projects address global environment challenges related to biodiversity conservation, climate change, international waters, land degradation, sustainable forest management, and chemicals and waste.

Of the GEF-supported projects, more than 1700 have been completed, accounting for $\$ 7.5$ billion in GEF grant funding. We presented a partial review of postcompletion sustainability of 53 of these projects in the GEF Independent Evaluation Office's (IEO) Annual Performance Report 2017 (GEF IEO, 2019). Since then, we have further deepened this analysis by including nine more completed projects and by reducing data gaps. Our analysis in this chapter covers 62 completed projects that were financed by the GEF and field verified 2 or more years after completion by the GEF IEO or the World Bank's Independent Evaluation Group (IEG).

We found that most of the projects predicted to be sustainable at project completion were indeed sustainable during the postcompletion period. The factors affecting actual accrual of benefits during the postcompletion period included quality of project design, availability of financing for follow-up activities, acceptance of the project among the key stakeholders, support from the political leadership, and institutional capacities of the executing partner.

\section{Understanding Sustainability}

The Brundtland Commission in 1987 defined sustainable development as "development that meets the needs of the present without compromising the ability of future generations to meet their own needs" (World Commission on Environment and Development, 1987, p. 41). The term sustainability, however, is used with various perspectives (White, 2013). For some, most important is an economic perspective focused on intergenerational tradeoffs, and a comparison of value and costs to the society (Solow, 1993; Stavins et al., 2003). For others, conservation of ecosystems and prevention of environmental degradation is an overriding consideration (Costanza \& Patten, 1995). Still others call for consideration of holistic approaches to understanding sustainability (Mebratu, 1998).

The principles of sustainable development and its application have been addressed by several scholars (Daly, 1990; Hardi, 1997; Lélé, 1991). Most consider social, economic, environmental, and institutional dimensions for sustainability assessment (Aarseth et al., 2017; Mebratu, 1998; Olsen \& Fenhann, 2008; Saysel et al., 2002; Singh et al., 2009). Scholars' assumptions were related to the what and how of sustainability assessment and can have ethical and practical implications in terms of the characteristics that gain prominence versus those left out of the discussion (Gasparatos, 2010). The focus of much of the work on sustainability assessment has centered on determining the extent to which development activities avoid harm to the environment and to social, economic, and other systems affected. Such focus leaves out assessment of the durability of development interventions, especially those aimed at delivering sustainable development.

Within the context of delivering development aid through projects, sustainability may be under- 
stood as "the extent to which the net benefits of the intervention continue, or are likely to continue" (Organisation for Economic Co-operation and Development Development Assistance Committee [OECD DAC] Network on Development Evaluation, 2019, p. 12). This perspective has been used in several studies that assess sustainability of development projects. However, Patton (2020) recently criticized the criterion, arguing that the OECD DAC's narrow definition is inadequate to assess systemic transformations and does not adequately address the broader issue of sustainability.

Hoque et al. (1996), who assessed sustainability of a water, sanitation, and hygiene education project in Bangladesh, found that acceptance of the promoted practices by the beneficiaries was an important factor in ensuring sustainability 6 years after implementation completion. Pollnac and Pomeroy (2005), who studied integrated coastal management, found that a community's perception of likely benefits from an intervention affected their continued involvement in project activities and, therefore, project sustainability. Martinot et al. (2001) found that, for projects focused on solar home systems, the extent to which the promoted model ensured profitability affected its sustainability. However, these analyses are limited to a small number of projects and generalizing the findings beyond their local implementation context is usually difficult.

International development organizations such as the Asian Development Bank (ADB), European Bank for Reconstruction and Development (EBRD), United Nations Development Programme (UNDP), United Nations Environment Programme (UNEP), International Fund for Agricultural Development (IFAD), and the GEF assess likelihood of sustainability of their completed projects. This likelihood is assessed at the point of project completion and considers the results achieved and risks to accrual of future benefits. Generally, $60 \%-70 \%$ of these agencies' completed projects are rated in the likely range for sustainability (GEF IEO, 2019). The organizations generally take financial (and/ or economic), sociopolitical, institutional, and environmental risks into account when assessing likelihood of sustainability.

\section{Analytical Framework}

In this chapter, we examine the extent to which completed projects are sustainable and the factors that affect sustainability. To assess project sustainability, we take stock of the accrued and likely benefits of projects that were completed more than 2 years prior to point of assessment. The projects covered focus on addressing environmental concerns, with benefit streams usually in the form of environmental stress reduction and improvement in environmental status, adoption of promoted technologies and approaches, changes in legal and policy environment, and improvements in institutional and individual capacities. The extent to which such expected benefits-that are demonstrably linked to project activities-accrue is a measure of the project's sustainability. Evaluators estimate the accrual of benefits and likelihood of future accrual for the time frame within which these benefits may be expected.

If the past benefit accrual and likely future accrual of a project (after accounting for risks) is close to the ex-ante projections, then the project is assessed as sustainable. Although the approach that international development organizations use to assess sustainability is analogous, our approach differs in that we make this assessment based on review of information on observed continuation of benefits gathered more than 2 years after project completion, rather than estimated likelihood of continuation of benefits at project completion. This means that assessment of project sustainability is informed more by data on actual accrual than by data on likelihood of future accrual.

The extent to which a project is sustainable may be affected by variables related to its design, implementation, and contextual factors. For example, in instances where recipient community support is important, the extent of attention to community consultations and outreach may 
play an important role in determining sustainability. Similarly, for a project addressing market barriers, the structure of incentives may determine how well a technology is adopted by producers and/or consumers. During implementation, attention to supervision, exit strategy, and capacity building of key institutions may affect sustainability. Timely availability of cofinancing may also enhance project sustainability. An account of such factors is provided in the project completion reports.

At project completion, the project's finances have been utilized and the project team dissolves. During the postcompletion period, project sustainability may be affected by factors such as host institutions mainstreaming project follow-up activities; support from the national government; presence of an enabling legal, policy, and regulatory environment; presence of a motivated leadership; market conditions; and general economic and political climate in the country. The account of how such factors affected a project's sustainability may be provided in the project's postcompletion evaluation report. We review these sources to gather information on the factors and mechanisms through which they affect project sustainability.

\section{Data}

The focus of our study was the project portfolio of the GEF, which provides financial support, mostly in the form of grants, for projects that address global environmental concerns. Of the 1700 completed projects, 147 received a postcompletion evaluation or a field verification by the GEF IEO or the implementing agency evaluation office. After screening the verification reports, we identified reports for 62 completed GEF projects as adequate in terms of quality of reporting on sustainability. We then reviewed the field verification reports for these projects in greater detail (see the chapter appendix for a complete list of the projects, their implementing agencies, and the countries in which the interventions took place).
The 62 projects address environmental concerns such as biodiversity conservation (23 projects), climate change (22 projects), chemicals (six projects), ozone depleting substances (four projects), international waters (four projects), and land degradation (one project); two projects addressed multiple focal areas. Fifty-three of the projects were implemented within a single country and nine were global or regional projects spanning multiple countries. In all, the projects with a national geographic scope covered 34 countries. GEF financing for these projects ranged from $\$ 0.5$ million to $\$ 35$ million, with an average of $\$ 8.1$ million.

The 62 projects were under implementation from 2 to 12 years, with an average duration of 6 years. On average, the last field verification was conducted 6 years after project completion; final field verifications ranged from 2 to 14 years postcompletion. The World Bank was the lead implementing agency for 42 projects, UNDP for 18 , and UNEP for one. Fifty-five of these projects were implemented by a single GEF Agency, with seven implemented jointly by two GEF Agencies.

\section{Methodology}

\section{Screening and Review}

We conducted this review in 2018-2020, identifying 147 completed GEF projects that had been covered through postcompletion evaluations and/ or field verifications (from here on referred to as postcompletion evaluation) by the GEF IEO or the GEF Agency evaluation offices. We screened these projects to ensure that the postcompletion evaluation took place at least 2 years after the implementation was completed. This ensured that enough time had elapsed after project completion to assess actual accrual of benefits during the postcompletion period. In this 2-year period, the project execution structure financed through the project funds is generally dismantled, longer term results of the project have greater time to manifest, and risks to accrual of benefits are more likely to have materialized. We screened out 35 
of the projects because their most recent postcompletion evaluation took place less than 2 years after project completion.

We surveyed the postcompletion evaluations to ensure that they provided adequate information on the project's postcompletion sustainability. We considered evaluation reports prepared by the GEF IEO and the publicly available postcompletion reports by the evaluation offices of the GEF Agencies. This ensured that the evidence provided in these reports was credible; that is, provided by individuals a step removed from project implementation.

Where a project was covered through more than more than one postcompletion evaluation or field verification report, we only considered those conducted 2 years or more after completion for assessment of sufficiency of evidence by these together. After the screening process, 62 projects were retained in the pool: 42 with postcompletion evaluation reports prepared by the GEF IEO and 20 with reports prepared by the World Bank's Independent Evaluation Group.

Our desk review of available project documents included the postcompletion evaluation and field verification reports, implementation completion reports, annual progress reports, midterm reviews, and project proposal documents. We compiled the information relevant to project sustainability using an instrument that gathered numerous information sources: outcome achievements at project completion and at postcompletion field verification, projected sustainability at project completion and observed sustainability at postcompletion, mechanisms through which the projects achieved long-term impacts, barriers restraining progress, and factors driving the changes. We then organized the information gathered through the instrument in a dataset to facilitate analysis.

\section{Assessment Approach}

To assess sustainability, we reviewed the information provided in the postcompletion evaluation reports and other project documents such as the terminal evaluation, annual progress reports, and midterm reviews. Sustainability was assessed on a 4-point scale: sustainable, moderately sustainable, moderately unsustainable, and unsustainable. In assessing performance, we considered:

- aspects such as financial, economic, social, political, and environmental sustainability

- probability and likely effect of a risk

- accrued and likely benefits

- time frame within which benefits are expected (ECG, 2012)

The assessment was both backward lookingtaking account of the accrued net benefits-and forward looking-estimating the likelihood of accrual of net benefits in future.

We assessed the extent to which environmental benefits - the focus of the covered projectshad accrued at the time when the postcompletion evaluation was conducted. We also documented instances where promoted interventions were reported to be adopted outside the framework of a given project through processes such as mainstreaming, replication, scaling-up, and market change. When documenting these broader adoption processes, we identified the elements of the GEF projects that were being adopted and the scale at which they were being adopted. For some of the interventions, such as protected area management and capacity development of institutions, sustaining the momentum created by the project is also an important characteristic.

\section{Limitations}

A comparison of the performance ratings of the projects at implementation completion (see Table 1) showed that the sustainability ratings of the projects covered through postcompletion review were significantly different from the other completed projects in the GEF portfolio. This may be due to a selection bias: Projects with implementation failure due to both endogenous and exogenous reasons are generally excluded from postcompletion review and postcompletion evaluations may implicitly give more attention to 
Table 1 Performance ratings at implementation completion: GEF projects rated in satisfactory/likely range as percentage of rated projects

\begin{tabular}{l|l|l}
\hline $\begin{array}{l}\text { Performance } \\
\text { dimension (binary } \\
\text { rating scale) }\end{array}$ & $\begin{array}{l}\text { Projects with } \\
\text { postcompletion } \\
\text { evaluation (62) }\end{array}$ & $\begin{array}{l}\text { Other projects } \\
(1644)\end{array}$ \\
\hline $\begin{array}{l}\text { Outcome } \\
\text { (Satisfactory - } \\
\text { Unsatisfactory) }\end{array}$ & $85 \%(61)$ & $80 \%(1625)$ \\
\hline $\begin{array}{l}\text { Sustainability } \\
\text { (Likely - Unlikely) }\end{array}$ & $\mathbf{7 8 \% * ( 5 9 )}$ & $\mathbf{6 2 \% * ( 1 5 2 4 )}$ \\
\hline $\begin{array}{l}\text { Implementation } \\
\text { (Satisfactory - } \\
\text { Unsatisfactory) }\end{array}$ & $83 \%(48)$ & $80 \%(1419)$ \\
\hline $\begin{array}{l}\text { M\&E } \\
\text { (Satisfactory - } \\
\text { Unsatisfactory) }\end{array}$ & $63 \%(43)$ & $65 \%(1455)$ \\
\hline
\end{tabular}

Source: GEF IEO (2020) dataset

Note. $*$ = statistically significant difference

projects that provide greater opportunity to test the given project's theory of change. On performance parameters such as outcome, quality of implementation, and quality of monitoring and evaluation (M\&E), the performance was not significantly different.

The postcompletion evaluations and field verifications that we reviewed were not conducted with the primary purpose of assessing sustainability. Most were completed as part of the field work to gather detailed information on a thematic area. These evaluations and verifications were conducted by different evaluators at different points in time (from 2004 to 2018). Further, the duration at which the postcompletion evaluation was conducted after project completion ranged from 2 to 14 years. This led to differences in the level of detail on issues related to sustainability in the reviewed documents.

\section{Findings}

The findings of the review indicated that, in general, the projects covered through postcompletion evaluations were sustainable. Although the sustainability outlook of some projects did deteriorate, this was balanced by improvement in the outlook for others. The review also showed that incidence of the catalytic processes of broader adoption-sustaining, mainstreaming, replication, scaling-up, and market change-was higher at postcompletion evaluation. These catalytic processes also covered more project interventions at postcompletion evaluation than at implementation completion. The review shows that factors such as financial support for follow-up, political support, follow-up by and capacities of the executing agency, stakeholder buy-in, and project design may play a crucial role in determining project sustainability.

\section{Sustainability During Postcompletion Period}

Most projects that were assessed at implementation completion as likely to sustain were also assessed as being sustainable during the postcompletion period (see Table 2). For several projects that were assessed as unlikely to sustain, the risks did not materialize. The revised assessment based on postcompletion evaluation placed these projects in the sustainable range. For two thirds of the completed projects, the outlook on risks to sustainability improved from the point of implementation completion to the postcompletion evaluation (see Table 3). The sustainability outlook deteriorated for only about one sixth of the projects.

About one third (31\%) of the projects achieved a higher level of outcome at postcompletion evaluation than at implementation completion (see Table 4), because the longer time frame since implementation facilitated greater progress. When compared to the status at implementation completion, the outcome achievement of a vast majority of projects was at the same level or higher at postcompletion evaluation.

\section{Broader Adoption and Sustainability}

Sustainability of a project is a function of whether the project's long-term effects are achieved. But seeing a project's environmental results manifest fully may take a long time. Similarly, some longterm effects may be attributed directly to a proj- 
Table 2 Distribution of completed projects based on their sustainability ratings

\begin{tabular}{l|l|l|l}
\hline & \multicolumn{3}{l}{ Assessed performance at postcompletion evaluation } \\
\hline Projected sustainability at implementation completion & Sustainable range & Unsustainable range & Total \\
\hline Likely range & $60 \%(37)$ & $15 \%(9)$ & $74 \%(46)$ \\
\hline Unlikely range & $11 \%(7)$ & $10 \%(6)$ & $21 \%(13)$ \\
\hline Not rated & $3 \%(2)$ & $2 \%(1)$ & $5 \%(3)$ \\
\hline Total & $74 \%(46)$ & $26 \%(16)$ & $100 \%(62)$ \\
\hline
\end{tabular}

Table 3 Change in likelihood of sustainability

\begin{tabular}{l|l|l|l|l|l}
\hline & \multicolumn{3}{l}{$\begin{array}{l}\text { Change in likelihood of sustainability at postcompletion versus at } \\
\text { completion }\end{array}$} \\
\hline Projected sustainability at project completion & Higher & Same & Lower & Unable to assess & Total \\
\hline Likely range & $13 \%(8)$ & $37 \%(23)$ & $13 \%(8)$ & $11 \%(7)$ & $74 \%(46)$ \\
\hline Unlikely range & $5 \%(3)$ & $11 \%(7)$ & $2 \%(1)$ & $3 \%(2)$ & $21 \%(13)$ \\
\hline Not rated & $0 \%(0)$ & $3 \%(2)$ & $0 \%(0)$ & $2 \%(1)$ & $5 \%(3)$ \\
\hline Total & $18 \%(11)$ & $52 \%(32)$ & $15 \%(9)$ & $16 \%(10)$ & $\begin{array}{l}100 \% \\
(62)\end{array}$ \\
\hline
\end{tabular}

Table 4 Change in level of project outcome achievement

\begin{tabular}{l|l|l|l|l|l}
\hline & \multicolumn{5}{|l}{ Outcome achievement at postcompletion versus at completion } \\
\hline Projected sustainability at project completion & Higher & Same & Lower & Unable to assess & Total \\
\hline Likely range & $21 \%(13)$ & $39 \%(24)$ & $11 \%(7)$ & $3 \%(2)$ & $74 \%(46)$ \\
\hline Unlikely range & $8 \%(5)$ & $8 \%(5)$ & $3 \%(2)$ & $2 \%(1)$ & $21 \%(13)$ \\
\hline Not rated & $2 \%(1)$ & $3 \%(2)$ & $0 \%(0)$ & $0 \%(0)$ & $5 \%(3)$ \\
\hline Total & $31 \%(19)$ & $50 \%(31)$ & $15 \%(9)$ & $5 \%(3)$ & $\begin{array}{l}100 \% \\
(62)\end{array}$ \\
\hline
\end{tabular}

Source for Tables 2, 3, and 4: GEF IEO (2020) dataset; review of postcompletion evaluations

ect while others may be attributed only indirectly because they involve catalytic processes and other actors. Broader adoption takes place when other stakeholders such as governments, private sector, civil society, and other donors (whether originally part of the project or not) adopt, expand, and build on initiatives through a variety of mechanisms (GEF IEO, 2019). These mechanisms include processes that sustain, mainstream, replicate, and/or scale up the supported approaches, and/or change the structure of the targeted markets. The data from the review shows that, indeed, incidence of the processes of broader adoption (such as sustaining, mainstreaming, and market change) was significantly higher at the point of the postcompletion evaluation than the point of implementation completion. Figure 1 provides a comparison of the incidence of these broader adoption processes at both points.
Although incidence of replication and scaling-up also showed nominal increase, those differences were not statistically significant. This finding is consistent with what one would expect in sustainable projects.

Higher incidence of broader adoption at postcompletion evaluation was also evident in several instances at a more granular level. Our review tracked the extent to which other actors were adopting interventions related to:

- technology dissemination

- governance arrangements (including development of legal and policy measures)

- management approaches (including development of management plans and strategies)

- development of institutional capacities (through training, awareness, and support for operational infrastructure) 


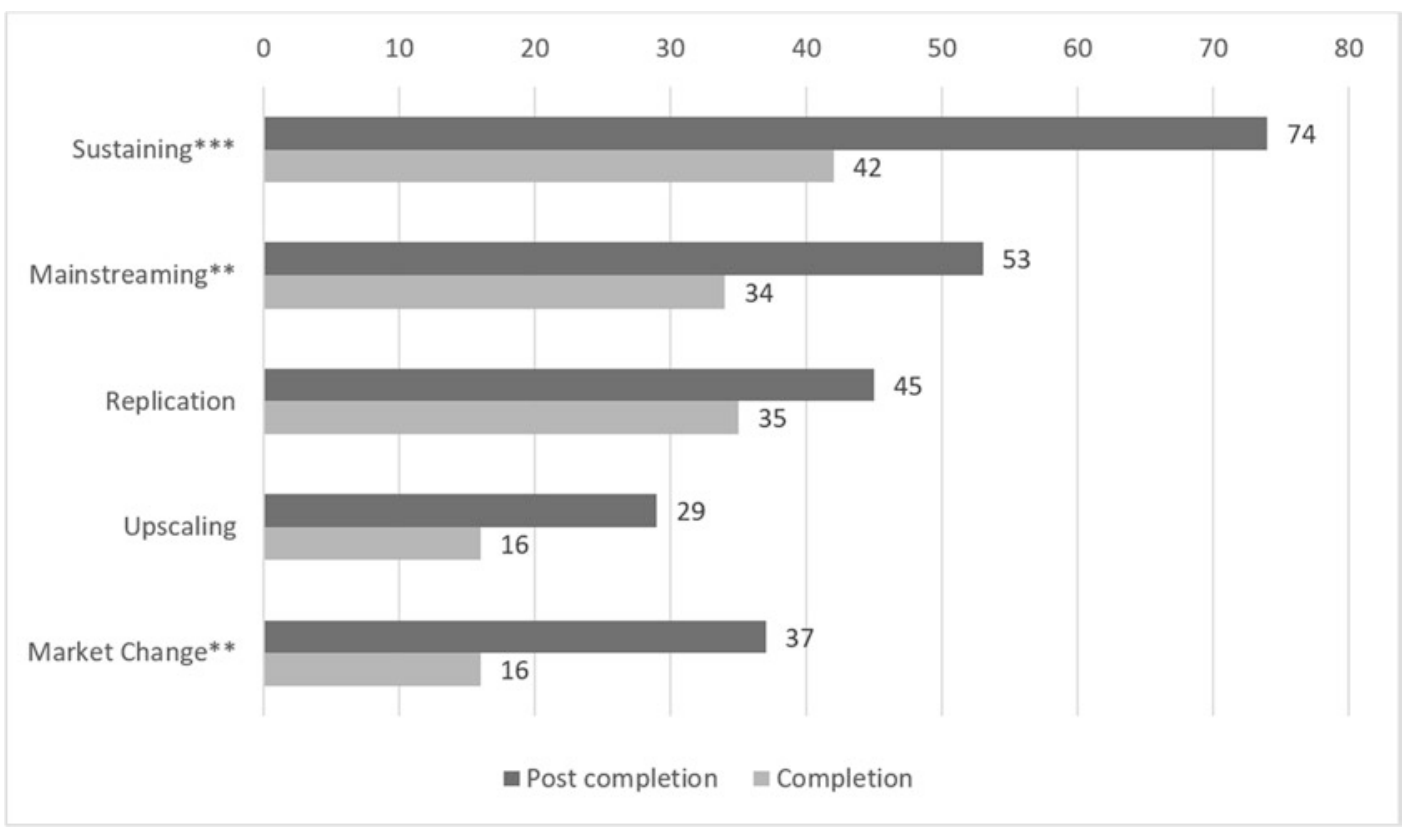

Fig. 1 Incidence of Broader Adoption Processes at Implementation Completion and at Postcompletion
Note. Graph shows percentage of projects studied $(N=62) ; * *=p<.001 ; * * *=p<.005$

Table 5 Broader adoption processes and the elements adopted

\begin{tabular}{l|l|l|l|l|l|l|l|l|l|l|l}
\hline & \multicolumn{3}{l}{ Sustaining } & \multicolumn{2}{l|}{ Mainstreaming } & \multicolumn{2}{l|}{ Replication } & \multicolumn{2}{l|}{ Scaling-up } & \multicolumn{2}{l}{ Market change } \\
\hline & PC & C & PC & C & PC & C & PC & C & PC & C \\
\hline Technology dissemination & $27^{*}$ & $11^{*}$ & 5 & 5 & 27 & 16 & 11 & 5 & $31^{*}$ & $15^{*}$ \\
\hline Governance arrangements & $39^{*}$ & $23^{*}$ & $44^{*}$ & $29 *$ & 3 & 2 & 10 & 11 & 16 & 6 \\
\hline Management approaches & $40^{* *}$ & $18^{* *}$ & 5 & 11 & 11 & 16 & 10 & 8 & 3 & 2 \\
\hline Institutional capacities & 39 & 37 & 16 & 15 & 23 & 21 & 13 & 6 & 11 & 5 \\
\hline
\end{tabular}

Note. Figures indicate percentage of projects studied $(N=62) ; P C$ postcompletion, $C$ project completion; $*=$ statistically significant difference at $90 \%$ confidence, $* *=$ at $95 \%$

Table 5, which presents the findings of this tracking, shows that several project elements were adopted by other actors for a higher percentage of projects at postcompletion evaluation than at implementation completion. Although for several project-supported interventions the difference in incidence of adoption was not statistically significant, the direction of change in general was consistent with an increase in broader adoption.

The review found that environmental status change and broader adoption was taking place at postcompletion for a nominally higher percentage of projects and at a higher scale. We assessed the scale at which environmental stress reduction and/or environmental status change (insignificant, local, large scale, or no change), and broader adoption, was taking place both at postcompletion evaluation and at implementation completion. Table 6 presents the findings of this assessment. It shows that environmental status change/stress reduction and broader adoption were taking place for a nominally higher percentage of projects, and at a large scale, at postcompletion evaluation than at implementation completion. Although the difference in incidence was not statistically significant, the direction of change was consistent with most projects being sustainable at project completion (see Table 2). 
Table 6 Environmental Status Change/Stress Reduction and Broader Adoption

\begin{tabular}{|c|c|c|}
\hline & At postcompletion & At completion \\
\hline \multicolumn{3}{|c|}{ Environmental status change/stress reduction } \\
\hline Yes & $69 \%$ & $61 \%$ \\
\hline At large scale & $39 \%$ & $34 \%$ \\
\hline At local scale & $31 \%$ & $27 \%$ \\
\hline No & $31 \%$ & $39 \%$ \\
\hline Insignificant scale & $13 \%$ & $15 \%$ \\
\hline No evidence & $18 \%$ & $24 \%$ \\
\hline \multicolumn{3}{|l|}{ Broader adoption } \\
\hline Yes & $84 \%$ & $75 \%$ \\
\hline At large scale & $45 \%$ & $35 \%$ \\
\hline At local scale & $39 \%$ & $40 \%$ \\
\hline No & $16 \%$ & $25 \%$ \\
\hline Insignificant scale & $5 \%$ & $21 \%$ \\
\hline No evidence & $11 \%$ & $3 \%$ \\
\hline
\end{tabular}

Note. Figures indicate percentage of projects studied $(N=62)$

\section{Factors that Facilitate Sustainability}

The narratives of the postcompletion evaluation reports discussed the factors that affected project outcomes and sustainability. These include financial support for follow-up, political support, follow-up by and capacities of the executing agency, stakeholder buy-in, and project design weaknesses.

\section{Financial Support for Follow-Up}

Availability of financial support for follow-up activities is an important factor in a project's sustainability. Projects for which key stakeholders (including national and local governments, development agencies, NGOs, and private sector organizations) provided support for follow-up faced reduced risks and were able to progress well toward achieving their long-term outcomes.

Of the 19 projects for which we assessed outcome achievement at postcompletion at a higher level than at implementation completion, availability of financial support for follow-up was a key factor in 12 projects (63\%). For example, the GEF-supported Mekong River Basin Water Utilization Project, implemented by the World Bank in Cambodia, Lao PDR, Thailand, and Vietnam, developed the procedures and guidelines for the Mekong River Commission for man- agement of the basin. These procedures and guidelines have been implemented through a series of follow-up projects funded through World Bank loans. In Mexico, the GEF-funded Introduction of Climate Friendly Measures in Transport project provided support for the development of the first bus rapid transit line in Mexico City. Thanks to sustained financial support by the government, more metrobus lines were subsequently added, leading to expansion of the lowcarbon public transit system.

Availability of financial support for follow-up also reduces risks to sustenance of the progress made by the project. For the Renewable Energy Development project in China, sustained government financial support and regulations have stabilized the changes in the renewable energy market and reduced the risk of losing the gains related to market transformation. In case of the Lewa Wildlife Conservancy project in Kenya, the risks to sustainability decreased because of an increase in the fundraising capacity of the conservancy and continued support from the government.

In contrast, lack of financial support for follow-up activities can adversely affect a project's ability to achieve its long-term outcomes. For example, the Caribbean Planning for Adaptation to Global Climate Change project established 18 stations to monitor sea level rise. However, postcompletion evaluation found that none of these stations were transmitting data consistently after project completion because network maintenance had not been funded and continuity in capacitybuilding efforts was lacking. Similarly, in Ethiopia, the Conservation and Sustainable Use of Medicinal Plants project aimed at supporting in situ conservation of medicinal plants in the Bale Mountains National Park. However, the park was under resourced and an expected follow-up project did not materialize. This affected implementation of the plans and guidelines developed as part of the project and its replication to other areas in the country.

\section{Political Support}

Political support for a project and its follow-up is another important factor that affects project sus- 
tainability. The support is especially important for projects that aim to influence the legal, policy, and regulatory framework of a country. In other projects, continued support from the political leadership may help government agencies and departments prioritize follow-up to a given project. Evidence from the postcompletion evaluations showed political support (or lack thereof) had a critical effect on project sustainability in several instances. Of the 19 projects with outcome achievement at a higher level at postcompletion evaluation than at implementation completion, strong political support was a key factor for 11 projects (58\%).

The China Renewable Energy Development project progressed well toward achieving its catalytic effects because the Chinese government adopted the Renewable Energy Law of 2006. Similarly, the India Ecodevelopment project, which piloted a financing mechanism in a protected area, received support from the political leadership that amended the nation's Wildlife Act to mandate that similar mechanisms be established in all tiger reserves. In Bulgaria, a high level of political support for the Ozone Depleting Substances Phase-out project led to sustained efforts for development of appropriate legislation; establishment of procedures to permit, record, and monitor production of ozonedepleting substances; and implementation of measures to address illegal trade of these substances.

\section{Follow-Up by, and Capacities of, Executing Partner}

The support provided by an international development agency through a project generally ends at implementation completion. Typically, activities are implemented on the ground by an executing agency that has a track record or mandate to address concerns that are the focus of the project. We found that, after implementation completion, the follow-up by the executing agency-and its capacities to follow up-seems to affect sustainability. This was a key factor in seven (37\%) of the 19 projects for which outcome achievement was higher at postcompletion evaluation than at implementation completion.

Several examples illustrate the role of executing agencies in facilitating project sustainability. The World Bank-implemented Alternate Energy project in India aimed at development of the renewable energy sector through support for small hydro projects, solar photovoltaic, and wind energy. One project component was to enhance the capacities of its executing partner, the Indian Renewable Energy Development Agency (IREDA), through technical support and training, and through support for enhancing its operational capacity. After completion of the project, IREDA has continued supporting renewable energy development projects and is able to carry out its mandate more effectively due to its enhanced capacities. IREDA's leadership has helped in enhancing the sustainability of the project. The Lewa Wildlife Conservancy Project in Kenya was executed by the Kenya Wildlife Conservancy, an NGO. After implementation completion, the conservancy has continued to create and manage new community conservancies that support wildlife populations, and this has enhanced the sustainability of the GEFsupported project outcomes.

\section{Stakeholder Buy-In}

Buy-in on the part of key stakeholders-or lack of it-appears important in determining project sustainability. Of the 19 projects for which outcome achievement was assessed to be at a higher level at postcompletion evaluation than at implementation completion, for six (32\%), strong stakeholder buy-in was a key factor in facilitating progress. Strong stakeholder involvement in the Ozone Depleting Substances Phase-out project in Bulgaria led to sustained efforts by the participating enterprises in maintaining equipment, which enhanced project sustainability. The Lewa Wildlife Conservancy project generated sustained support from local communities and national government by providing representation to the national and local government on the Lewa Wildlife Conservancy board. That sustained 
political support helped in replication of community conservancies in the region, and buy-in from local communities facilitated the efficient creation and management of new community conservancies, which have contributed to the outcomes of stable and improving wildlife populations.

\section{Project Design}

Each project is expected to be well designed so that the scarce resources are used for activities that are relevant, effective, and efficient. The project design should address key risks to the project and incorporate measures to mitigate risks that may jeopardize progress. Identifying examples where appropriate design made a project relevant and effective is difficult, but weaknesses in project design that limit a project's ability to achieve its long-term outcomes are more apparent.

In several projects, weaknesses in project design negatively affected progress and sustainability. The design of the Caribbean Planning for Adaptation to Global Climate Change project did not give attention to maintenance of the sea level rise monitoring stations created by the project. This affected functioning of these stations: Three years after project completion, none of the stations were transmitting data consistently. In Romania, the progress made by the Danube Delta Biodiversity project was jeopardized because the project did not adequately consider livelihood concerns of the residents of the Danube Delta area, making it difficult to sustain these communities' interest in conservation. The design of the Ship-Generated Waste Management project, which covered countries in the Caribbean islands, did not anticipate that ship-generated waste at sea (driven by cruise ships) would be a substantial contributor to pollution compared to waste that enters the land-based system. Instead of contributing to reduction of ship-generated waste, the project focused more on the threat from marine and coastal solid waste pollution to the land-based system. After project completion, this was assessed to be a major missed opportunity for the project and the gains from the project were limited because the main concern was not addressed.

\section{Conclusion}

Although the sustainability outlook of some projects changed from sustainable to unsustainable (or the reverse) with time, the review found little difference in the percentage of projects that were sustainable at the postcompletion evaluation. Passage of time allowed several long-term outcomes of the projects to manifest. It also allowed catalytic processes of broader adoption to take root-in several instances, interventions supported by the projects were being sustained, mainstreamed, replicated, scaled up, and/or leading to market change.

The completed projects covered in the review were somewhat higher achieving projects to begin with. Therefore, the performance of an average approved project would be somewhat lower because the average would include projects that experienced implementation failure (these are generally excluded from postcompletion evaluations) or unsatisfactory outcomes (generally underrepresented in postcompletion evaluations). Nonetheless, results do show that in most instances, projects that are assessed to have performed well at implementation completion are able to sustain their performance. This allays a major concern in the development community that gains made up to implementation completion may be lost during the postcompletion period.

Our review showed that numerous factors may affect sustainability, including availability of financial support for follow-up, political support for the project, follow-up by and capacities of the executing partner, stakeholder buy-in, and shortcomings in project design. These factors should be given attention to improve likelihood of sustainability of development projects. 


\section{Appendix: Completed GEF-funded Projects with Postcompletion Evaluation}

\begin{tabular}{|c|c|c|c|}
\hline $\begin{array}{l}\text { GEF } \\
\text { ID }\end{array}$ & Project Name & $\begin{array}{l}\text { Implementing } \\
\text { Agency }\end{array}$ & Country \\
\hline 15 & $\begin{array}{l}\text { Programme for Phasing Out Ozone } \\
\text { Depleting Substances }\end{array}$ & $\begin{array}{l}\text { UNDP/ } \\
\text { UNEP }\end{array}$ & Tajikistan \\
\hline 18 & Kenya - Lewa Wildlife Conservancy & World Bank & Kenya \\
\hline 49 & Coastal Wetlands Management & World Bank & Ghana \\
\hline 50 & $\begin{array}{l}\text { Kenya - Conservation of the Tana River } \\
\text { Primate National Reserve }\end{array}$ & World Bank & Kenya \\
\hline 54 & $\begin{array}{l}\text { Bwindi Impenetrable National Park and } \\
\text { Mgahinga Gorilla National Park } \\
\text { Conservation }\end{array}$ & World Bank & Uganda \\
\hline 57 & Biodiversity Conservation & World Bank & Bolivia \\
\hline 59 & $\begin{array}{l}\text { Regional - OECS Ship-Generated Waste } \\
\text { Management }\end{array}$ & World Bank & $\begin{array}{l}\text { Regional (Antigua and Barbuda, Dominica, } \\
\text { Grenada, St. Kitts and Nevis, St. Lucia, St. } \\
\text { Vincent and Grenadines) }\end{array}$ \\
\hline 64 & Demand Side Management Demonstration & World Bank & Jamaica \\
\hline 69 & Danube Delta Biodiversity & World Bank & Romania \\
\hline 71 & $\begin{array}{l}\text { In-Situ Conservation of Genetic } \\
\text { Biodiversity }\end{array}$ & World Bank & Turkey \\
\hline 74 & $\begin{array}{l}\text { Ozone Depleting Substance Consumption } \\
\text { Phase-out (first tranche) }\end{array}$ & World Bank & Russian Federation \\
\hline 76 & Alternate Energy & World Bank & India \\
\hline 84 & India - Ecodevelopment & $\begin{array}{l}\text { World Bank/ } \\
\text { UNDP }\end{array}$ & India \\
\hline 90 & Russia Biodiversity Conservation Project & World Bank & Russian Federation \\
\hline 93 & $\begin{array}{l}\text { Ozone Depleting Substances Phase-out } \\
\text { Project }\end{array}$ & World Bank & Bulgaria \\
\hline 94 & $\begin{array}{l}\text { Technical Support and Investment Project } \\
\text { for the Phaseout of Ozone Depleting } \\
\text { Substances }\end{array}$ & World Bank & Hungary \\
\hline 100 & Danube Delta Biodiversity & World Bank & Ukraine \\
\hline 105 & $\begin{array}{l}\text { Caribbean Planning for Adaptation to } \\
\text { Global Climate Change (CARICOM) }\end{array}$ & World Bank & $\begin{array}{l}\text { Regional (Antigua and Barbuda, Barbados, } \\
\text { Bahamas, Belize, Dominica, Grenada, } \\
\text { Guyana, Jamaica, St. Kitts and Nevis, St. } \\
\text { Lucia, Trinidad and Tobago, St. Vincent and } \\
\text { Grenadines) }\end{array}$ \\
\hline 107 & $\begin{array}{l}\text { Ukraine - Ozone Depleting Substances } \\
\text { Phaseout }\end{array}$ & World Bank & Ukraine \\
\hline 112 & $\begin{array}{l}\text { Photovoltaic Market Transformation } \\
\text { Initiative }\end{array}$ & $\begin{array}{l}\text { World Bank/ } \\
\text { IFC }\end{array}$ & Global (Kenya, India, Morocco) \\
\hline 114 & $\begin{array}{l}\text { Russian Federation - Ozone Depleting } \\
\text { Substance Consumption Phaseout Project }\end{array}$ & World Bank & Russian Federation \\
\hline 115 & Phaseout of Ozone Depleting Substances & World Bank & Poland \\
\hline 134 & $\begin{array}{l}\text { South Africa - Cape Peninsula Biodiversity } \\
\text { Conservation Project }\end{array}$ & World Bank & South Africa \\
\hline 192 & $\begin{array}{l}\text { Bhutan Integrated Management of Jigme } \\
\text { Dorji National Park (JDNP) }\end{array}$ & UNDP & Bhutan \\
\hline 292 & $\begin{array}{l}\text { Russian Federation - Capacity Building to } \\
\text { Reduce Key Barriers to Energy Efficiency } \\
\text { in Russian Residential Buildings and Heat } \\
\text { Supply }\end{array}$ & UNDP & Russian Federation \\
\hline 325 & $\begin{array}{l}\text { Coal Bed Methane Capture and Commercial } \\
\text { Utilization }\end{array}$ & UNDP & India \\
\hline
\end{tabular}




\begin{tabular}{|c|c|c|c|}
\hline $\begin{array}{l}\text { GEF } \\
\text { ID }\end{array}$ & Project Name & $\begin{array}{l}\text { Implementing } \\
\text { Agency }\end{array}$ & Country \\
\hline 344 & $\begin{array}{l}\text { Lithuania Phase Out of Ozone Depleting } \\
\text { Substances }\end{array}$ & $\begin{array}{l}\text { UNDP/ } \\
\text { UNEP }\end{array}$ & Lithuania \\
\hline 351 & $\begin{array}{l}\text { Ethiopia - A Dynamic Farmer-Based } \\
\text { Approach to the Conservation of Plant } \\
\text { Genetic Resources }\end{array}$ & UNDP & Ethiopia \\
\hline 358 & $\begin{array}{l}\text { Sustainable Development and Management } \\
\text { of Biologically Diverse Coastal Resources }\end{array}$ & UNDP & Belize \\
\hline 370 & $\begin{array}{l}\text { India - Development of High-Rate } \\
\text { Biomethanation Processes as Means of } \\
\text { Reducing Greenhouse Gas Emissions }\end{array}$ & UNDP & India \\
\hline 386 & $\begin{array}{l}\text { India - Optimizing Development of Small } \\
\text { Hydel Resourcces in the Hilly Regions of } \\
\text { India }\end{array}$ & UNDP & India \\
\hline 404 & Energy Efficiency & World Bank & India \\
\hline 445 & $\begin{array}{l}\text { Barrier Removal for the Widespread } \\
\text { Commercialization of Energy-Efficient } \\
\text { CFC-Free Refrigerators in China }\end{array}$ & UNDP & China \\
\hline 446 & Renewable Energy Development & World Bank & China \\
\hline 593 & $\begin{array}{l}\text { Programme for Phasing Out Ozone } \\
\text { Depleting Substances }\end{array}$ & $\begin{array}{l}\text { UNDP/ } \\
\text { UNEP }\end{array}$ & Turkmenistan \\
\hline 615 & $\begin{array}{l}\text { Mekong River Basin Water Utilization } \\
\text { Project }\end{array}$ & World Bank & $\begin{array}{l}\text { Regional (Cambodia, Lao PDR, Thailand, } \\
\text { Vietnam) }\end{array}$ \\
\hline 631 & $\begin{array}{l}\text { Conservation and Sustainable Use of } \\
\text { Medicinal Plants }\end{array}$ & World Bank & Ethiopia \\
\hline 643 & Renewable Energy for Agriculture & World Bank & Mexico \\
\hline 769 & $\begin{array}{l}\text { Programme for Phasing Out Ozone } \\
\text { Depleting Substances }\end{array}$ & $\begin{array}{l}\text { UNDP/ } \\
\text { UNEP }\end{array}$ & Kazakhstan \\
\hline 778 & $\begin{array}{l}\text { Indigenous and Community Biodiversity } \\
\text { Conservation (COINBIO) }\end{array}$ & World Bank & Mexico \\
\hline 784 & $\begin{array}{l}\text { Methane Capture and Use (Landfill } \\
\text { Demonstration Project) }\end{array}$ & World Bank & Mexico \\
\hline 818 & $\begin{array}{l}\text { Conservation of Globally Threatened } \\
\text { Species in the Rainforests of Southwest Sri } \\
\text { Lanka }\end{array}$ & UNDP & Sri Lanka \\
\hline 837 & $\begin{array}{l}\text { Conservation and Sustainable Use of the } \\
\text { Mesoamerican Barrier Reef }\end{array}$ & World Bank & $\begin{array}{l}\text { Regional (Belize, Guatemala, Honduras, } \\
\text { Mexico) }\end{array}$ \\
\hline 878 & $\begin{array}{l}\text { Protected Area Management and Wildlife } \\
\text { Conservation }\end{array}$ & $\begin{array}{l}\text { World Bank/ } \\
\text { ADB }\end{array}$ & Sri Lanka \\
\hline 885 & $\begin{array}{l}\text { Reversing Environmental Degradation } \\
\text { Trends in the South China Sea and Gulf of } \\
\text { Thailand }\end{array}$ & UNEP & $\begin{array}{l}\text { Regional (Cambodia, China, Indonesia, } \\
\text { Malaysia, Philippines, Thailand, Vietnam) }\end{array}$ \\
\hline 941 & $\begin{array}{l}\text { China - Demonstration for Fuel-Cell Bus } \\
\text { Commercialization }\end{array}$ & UNDP & China \\
\hline 945 & National Protected Areas System & World Bank & Ecuador \\
\hline 1058 & $\begin{array}{l}\text { Pacific Islands Renewable Energy } \\
\text { Programme (PIREP) }\end{array}$ & UNDP & $\begin{array}{l}\text { Regional (Cook Islands, Fiji, Micronesia, } \\
\text { Kiribati, Marshall Islands, Nauru, Niue, } \\
\text { Papua New Guinea, Palau, Samoa, Solomon } \\
\text { Islands, Tonga, Tuvalu, Vanuatu) }\end{array}$ \\
\hline 1079 & $\begin{array}{l}\text { Off-Grid Rural Electrification for } \\
\text { Development (PCH / PERZA) }\end{array}$ & $\begin{array}{l}\text { UNDP/World } \\
\text { Bank }\end{array}$ & Nicaragua \\
\hline
\end{tabular}




\begin{tabular}{|c|c|c|c|}
\hline $\begin{array}{l}\text { GEF } \\
\text { ID }\end{array}$ & Project Name & $\begin{array}{l}\text { Implementing } \\
\text { Agency }\end{array}$ & Country \\
\hline 1084 & $\begin{array}{l}\text { Mainstreaming Adaptation to Climate } \\
\text { Change Project (MACC) }\end{array}$ & World Bank & $\begin{array}{l}\text { Regional (Antigua and Barbuda, Barbados, } \\
\text { Bahamas, Belize, Dominica, Grenada, } \\
\text { Guyana, Jamaica, St. Kitts and Nevis, St. } \\
\text { Lucia, Trinidad and Tobago, St. Vincent and } \\
\text { Grenadines) }\end{array}$ \\
\hline 1124 & $\begin{array}{l}\text { Integrated Participatory Ecosystem } \\
\text { Management in and Around Protected } \\
\text { Areas, Phase I }\end{array}$ & UNDP & Cabo Verde \\
\hline 1155 & $\begin{array}{l}\text { Introduction of Climate Friendly Measures } \\
\text { in Transport }\end{array}$ & World Bank & Mexico \\
\hline 1356 & Forest Sector Development Project & World Bank & Vietnam \\
\hline 1544 & $\begin{array}{l}\text { Rio de Janeiro Integrated Ecosystem } \\
\text { Management in Production Landscapes of } \\
\text { the North-Northwestern Fluminense }\end{array}$ & World Bank & Brazil \\
\hline 1682 & $\begin{array}{l}\text { Facilitating and Strengthening the } \\
\text { Conservation Initiatives of Traditional } \\
\text { Landholders and Their Communities to } \\
\text { Achieve Biodiversity Conservation } \\
\text { Objectives }\end{array}$ & UNDP & Vanuatu \\
\hline 1872 & $\begin{array}{l}\text { Community Agriculture and Watershed } \\
\text { Management }\end{array}$ & World Bank & Tajikistan \\
\hline 2767 & $\begin{array}{l}\text { LAC Regional Sustainable Transport and } \\
\text { Air Quality Project }\end{array}$ & World Bank & Regional (Argentina, Brazil, Mexico) \\
\hline 2947 & $\begin{array}{l}\text { Renewable Energy and Rural Electricity } \\
\text { Access (RERA) }\end{array}$ & World Bank & Mongolia \\
\hline 2952 & Thermal Power Efficiency & World Bank & China \\
\hline 3148 & $\begin{array}{l}\text { DBSB Agricultural Pollution Control } \\
\text { Project - under the Strategic Partnership } \\
\text { Investment Fund for Nutrient Reduction in } \\
\text { the Danube River and Black Sea }\end{array}$ & World Bank & Croatia \\
\hline 3510 & $\begin{array}{l}\text { LDC/SIDS Portfolio Project: Capacity } \\
\text { Building for Sustainable Land Management } \\
\text { in Sierra Leone }\end{array}$ & UNDP & Sierra Leone \\
\hline 3973 & Armenia Energy Efficiency Project & World Bank & Armenia \\
\hline
\end{tabular}

\section{References}

Aarseth, W., Ahola, T., Aaltonen, K., Økland, A., \& Andersen, B. (2017). Project sustainability strategies: A systematic literature review. International Journal of Project Management, 35(6), 1071-1083. https:// doi.org/10.1016/j.ijproman.2016.11.006.

Costanza, R., \& Patten, B. C. (1995). Defining and predicting sustainability. Ecological Economics, 15(3), 193-196.

Daly, H. E. (1990). Toward some operational principles of sustainable development. Ecological Economics, 2(1), 1-6.

Evaluation Cooperation Group. (2012). Big book on evaluation good practice standards. Author. https://www. ecgnet.org/documents/4792/download https://ecgnet. org/document/ecg-big-book-good-practice-standards

Gasparatos, A. (2010). Embedded value systems in sustainability assessment tools and their implications. Journal of Environmental Management, 91(8), 1613-1622. https://doi.org/10.1016/j. jenvman.2010.03.014.

Global Environment Facility Independent Evaluation Office. (2019). GEF annual performance report 2017 (Evaluation report No. 136). https://www.gefieo.org/ evaluations/annual-performance-report-apr-2017

Global Environment Facility Independent Evaluation Office. (2020). Annual performance report 2020. https://www.gefieo.org/evaluations/annualperformance-report-apr-2020 
Hardi, P. (1997). Assessing sustainable development: Principles in practice (Vol. 26). International Institute for Sustainable Development.

Hoque, B. A., Juncker, T., Sack, R. B., Ali, M., \& Aziz, K. M. (1996). Sustainability of a water, sanitation and hygiene education project in rural Bangladesh: A 5-year follow-up. Bulletin of the World Health Organization, 74(4), 431.

Lélé, S. M. (1991). Sustainable development: A critical review. World Development, 19(6), 607-621.

Martinot, E., Cabraal, A., \& Mathur, S. (2001). World Bank/GEF solar home system projects: Experiences and lessons learned 1993-2000. Renewable and Sustainable Energy Reviews, 5(1), 39-57.

Mebratu, D. (1998). Sustainability and sustainable development: Historical and conceptual review. Environmental Impact Assessment Review, 18(6), 493-520.

OECD DAC Network on Development Evaluation. (2019). Better criteria for better evaluation: Revised evaluation criteria definitions and principles for use. Organisation for Economic Co-operation and Development. http://www.oecd.org/dac/evaluation/ revised-evaluation-criteria-dec-2019.pdf

Olsen, K. H., \& Fenhann, J. (2008). Sustainable development benefits of clean development mechanism projects: A new methodology for sustainability assessment based on text analysis of the project design documents submitted for validation. Energy Policy, 36(8), 28192830. https://doi.org/10.1016/j.enpol.2008.02.039.

Patton, M. Q. (2020). Evaluation criteria for evaluating transformation: Implications for the coronavi- rus pandemic and the global climate emergency. American Journal of Evaluation, 2020. https://doi. org/10.1177/1098214020933689.

Pollnac, R. B., \& Pomeroy, R. S. (2005). Factors influencing the sustainability of integrated coastal management projects in the Philippines and Indonesia. Ocean \& Coastal Management, 48(3-6), 233-251.

Saysel, A. K., Barlas, Y., \& Yenigün, O. (2002). Environmental sustainability in an agricultural development project: A system dynamics approach. Journal of Environmental Management, 64(3), 247-260.

Singh, R. K., Murty, H. R., Gupta, S. K., \& Dikshit, A. K. (2009). An overview of sustainability assessment methodologies. Ecological Indicators, 9(2), 189-212. https://doi.org/10.1016/j.ecolind.2011.01.007.

Solow, R. (1993). An almost practical step toward sustainability. Resources Policy, 19(3), 162-172. https://doi. org/10.1016/0301-4207(93)90001-4.

Stavins, R. N., Wagner, A. F., \& Wagner, G. (2003). Interpreting sustainability in economic terms: dynamic efficiency plus intergenerational equity. Economics Letters, 79(3), 339-343. https://doi.org/10.1016/ S0165-1765(03)00036-3.

White, M. A. (2013). Sustainability: I know it when I see it. Ecological Economics, 86, 213-217. https://doi. org/10.1016/j.ecolecon.2012.12.020.

World Commission on Environment and Development. (1987). Report of the World Commission on Environment and Development: Our common future. https://sustainabledevelopment.un.org/content/ documents/5987our-common-future.pdf

Open Access This chapter is licensed under the terms of the Creative Commons Attribution 4.0 International License (http://creativecommons.org/licenses/by/4.0/), which permits use, sharing, adaptation, distribution and reproduction in any medium or format, as long as you give appropriate credit to the original author(s) and the source, provide a link to the Creative Commons license and indicate if changes were made.

The images or other third party material in this chapter are included in the chapter's Creative Commons license, unless indicated otherwise in a credit line to the material. If material is not included in the chapter's Creative Commons license and your intended use is not permitted by statutory regulation or exceeds the permitted use, you will need to obtain permission directly from the copyright holder. 